\title{
Zuzanna Kowalczyk*
}

https://orcid.org/0000-0003-0475-3184

\section{Konflikty klimatyczne w dobie pandemii COVID-19 w Ameryce Łacińskiej}

\begin{abstract}
Abstrakt
Artykuł dotyczy zaostrzenia się konfliktów klimatycznych - głównie w Amazonii - w okresie pandemii COVID-19, ponieważ generująca je, niezgodna z prawem działalność wydobywcza, nasiliła się w tym czasie. Ponadto pociągnęła ze sobą skutki nie tylko związane $\mathrm{z}$ biodegradacją środowiska, ale również w wymiarze zagrożenia zdrowotnego, związanego z epidemią, dla społeczności rdzennych. Autorka odnosi się do rozwoju poszerzenia pojęcia bezpieczeństwa o zagadnienie ekologii, jak również szerszego zainteresowania degradacją środowiska jako przyczyny konfliktów, w których strony uciekają się do przemocy. Następnie nakreślona zostaje współczesna sytuacja w Amazonii w wybranym regionie, wskazane przyczyny nasilenia się zjawiska nielegalnego wydobycia złota, związanego w dużym stopniu $\mathrm{z}$ wybuchem globalnej pandemii. Jednym z celów autorki jest również przedstawienie możliwych działań, które możemy podjąć zarówno indywidualnie, jak i w wymiarze międzynarodowym, aby zmniejszyć skalę występowania konfliktów klimatycznych w przyszłości. Autorka musi zaznaczyć, iż z uwagi na okres, do jakiego się odnosi w artykule, został on oparty w większości na informacjach udostępnianych przede wszystkim przez rzetelne źródła medialne, w tym internetowe.
\end{abstract}

Słowa kluczowe: nielegalny przemysł wydobywczy, Amazonia, konflikty klimatyczne.

\section{Climate conflicts during the COVID-19 pandemic in Latin America}

\begin{abstract}
The article tackles the problem of climate conflicts - particularly in Amazon region and especially in the period of global pandemic COVID-19. This specific period was chosen deliberately, because the illegal mining activity, which generates and fuels this conflicts, has increased exponentially during this time. Moreover it brought not only negative

Adiunkt, politolog, Uniwersytet Łódzki, Wydział Studiów Międzynarodowych i Politologicznych, Katedra Studiów Latynoamerykańskich; e-mail: zuzanna.kowalczyk@uni.lodz.pl
\end{abstract}


consequences for the environment, but also puts in danger the health and mere existence of some of indigenous groups, caused by the spreading of the pandemic. Firstly, the author refers to the short history of inclusion into the field of security studies of the ecological perspective, as well as of the development of the interests in research connecting the degradation of natural environment with violent conflicts. In the context of Amazon region the outline of current situation, the causes of intensification of illegal gold mining are presented. The author also tries to identify possible actions that may be undertaken to reduce the risks of such conflicts in the future.

Keywords: illegal mining industry, Amazon region, climate conflicts.

Celem autorki jest przedstawienie konfliktu klimatycznego w Amazonii, dotyczącego zanieczyszczenia zasobów wodnych przez nielegalne górnictwo. Autorka skupiła się na okresie pandemii COVID-19, z uwagi na fakt, iż niezgodna z prawem działalność wydobywcza nasiliła się w tym czasie, jednocześnie przynosząc skutki nie tylko dotyczące biodegradacji środowiska, ale również zdrowotne, związane $\mathrm{z}$ epidemią dla społeczności rdzennych. Ponadto akurat w tym okresie udało się zarejestrować na zdjęciach wykonanych z Międzynarodowej Stacji Kosmicznej skalę tejże działalności. Fotografie te znalazły się w mediach na całym świecie, spotykając się z zainteresowaniem opinii publicznej i dając możliwość nagłośnienia opisywanego w artykule problemu, który w Europie i Polsce jest mniej znany odbiorcom. Autorka planuje wyjść od krótkiej ewolucji definicji pojęcia bezpieczeństwa, aby pokazać, że konflikty spowodowane zmianami klimatu mieszczą się w kategorii bezpieczeństwa. Przybliża również zagadnienie konfliktu klimatycznego, przywołując wojnę w Sudanie, gdyż jest ona często określana jako „pierwszy konflikt spowodowany zmianami klimatu”. Przechodząc do regionu południowoamerykańskiego, odnosi się do nielegalnej działalności wydobywczej, akcentuje jej wpływ na ludność rdzenną i łamanie jej praw, które powinny być chronione jako znajdujące się w kanonie praw człowieka. Autorka pragnie zaznaczyć, iż z uwagi na okres, jaki opisuje, musiała opierać się $\mathrm{w}$ większości na informacjach udostępnianych przede wszystkim przez rzetelne źródła medialne, w tym internetowe, sprawdzając jednak ich miarodajność i kompetencje autorów. W podsumowaniu stara się przedstawić czynniki, które spowodowały nasilenie się nielegalnego wydobycia złota w Amazonii oraz wybrane działania, które mogłyby w dłuższej perspektywie mieć pozytywny wpływ na ochronę środowiska naturalnego w Amazonii. 


\section{Wstęp}

W dzisiejszych naukach o bezpieczeństwie dominuje przekonanie, iż nie jest to pojęcie proste do zdefiniowania, o czym świadczy fakt, iż jego znaczenie zależy od przyjętej perspektywy. Jeśli przyjmiemy punkt widzenia mieszkańca Europy, Afryki, Ameryki Południowej to odpowiedzi na pytanie „Czym jest bezpieczeństwo?” mogą być bardzo rozbieżne. W tym zakresie nie ma już właściwie wątpliwości - definiowanie tego pojęcia zmienia się wraz z przyjętą perspektywą, jak i ze zmieniającymi się warunkami. Udowodniła to także pandemia COVID-19, która dla wielu osób zmieniła - nawet jeśli tylko na okres epidemii - postrzeganie tego, kiedy czujemy się bezpieczni.

$\mathrm{Na}$ fakt, iż bezpieczeństwo to kategoria cechująca się niejednoznacznością i elastycznością zwraca uwagę Paul D. Williams, podkreślając, iż bezpieczeństwo związane jest $\mathrm{z}$ kontrolą tego, co może stanowić zagrożenie dla „szczególnie cenionych" wartości ${ }^{1}$. Wartości, to co cenimy najbardziej, mogą być bardzo subiektywne - od nas zależy, co uważamy za najbardziej wartościowe. Jest to również widoczne w konfliktach o zasoby naturalne, których wartość jest inaczej szacowana - z jednej strony przez rządy, polityków, ale też przedstawicieli biznesu; a zupełnie inaczej przez lokalne społeczności, ludność autochtoniczną, grupy najuboższych mieszkańców. Dotyczy to nawet tak podstawowego zasobu, jak woda pitna. Można powiedzieć, iż niekiedy w tym wypadku istnieje przepaść między postrzeganiem wartości tych zasobów i ich wpływie na poczucie bezpieczeństwa przez wymienione grupy. Williams wskazuje, że hierarchia zagrożeń również może być inna - w omawianym przypadku zależnie od tego, czy obawiamy się braku możliwości zaspokojenia podstawowej potrzeby, jaką jest pragnienie, czy spadku zysków i wpływów do budżetu państwa.

Nie ulega jednak wątpliwości, że w dzisiejszym rozumieniu bezpieczeństwa nie można pominąć zagrożeń społecznych, gospodarczych, poza konfliktami zbrojnymi czy np. terroryzmem. Pandemia uświadomiła również w dotkliwy sposób opinii publicznej, jak ważne jest bezpieczeństwo związane ze sprawnymi systemami opieki zdrowotnej. Dotychczas podejście decydentów odbiegało od zmieniającej się perspektywy w nauce, którzy wydawali się być przywiązani do rozumienia bezpieczeństwa w kategorii potęgi i wojskowości. Pokazuje to porównanie wydatków w skali świata na siły zbrojne sięgające niemal 1900 kwintylionów dolarów w 2019 r. z wydatkami na służbę zdrowia - niecałe 8 kwintylionów w 2018 r. ${ }^{2}$ (dane Banku Światowego; w momencie pisania

P. D. Williams (red.), Studia bezpieczeństwa, Kraków 2012, s. 1-11.

2 Dane z bazy Banku Światowego, World Bank Open Data, https://data.worldbank.org (dostęp: 1.07.2021). 
artykułu nie opublikowano jeszcze danych - odpowiednio - za rok 2020 i 2019, a autorka nie chciała porównywać danych pochodzących z różnych źródeł, aby nie zaistniały różnice $\mathrm{w}$ zastosowanej przez instytucje metodzie ich gromadzenia i przeliczenia). Mimo że wydatki na ochronę zdrowia rosną, to dysproporcje są ogromne, dostrzegalne szczególnie wyraźnie obecnie - gdy w czasie pandemii służba zdrowia na świecie znajduje się w kryzysie (zwłaszcza, że zwraca się uwagę, iż nakłady na służbę zdrowia rosną przede wszystkim z powodu rosnących cen leków i sprzętu, zatem wzrost wydatków niekoniecznie przekłada się na zwiększenie jakości i dostępności opieki zdrowotnej).

Wraz z rozwojem pojęcia bezpieczeństwa w nauce, zwrócono uwagę, iż to niekoniecznie państwa, lecz jednostki ludzkie są podstawowym jego podmiotem. Zaś bezpieczeństwo jednostek przekłada się na bezpieczeństwo większych grup, zbiorowości czy społeczeństw. Ostatnio zaczęto z większą uwagą traktować zagrożenia dotyczące całej planety, gdyż bezpieczeństwo globu dotyczy całej populacji ludzkiej. Stąd pojawiło się podejście, iż polityka bezpieczeństwa nie tylko powinna obejmować wymiar ekologiczny, ale wręcz od niego się zaczynać. Badacze zaczęli zwracać uwagę, iż środowisko naturalne stanowi podstawę, bez której niemożliwa jest żadna inna działalność człowieka zależnego od prawidłowego funkcjonowania ekosystemów ${ }^{3}$. Jeśli nawet to podejście nie dominuje, to coraz szerzej jest akceptowane, dlatego przydatne jest jako wstęp do dalszych rozważań autorki.

\section{Konflikt w Darfurze - pierwszym zbrojnym konfliktem klimatycznym?}

Właściwie nie kwestionuje się obecnie twierdzenia, że konflikty o zasoby spowodowane zmianami w środowisku naturalnym będą przybierać na sile w XXI w. Tego rodzaju konflikty nazywane są również klimatycznymi. Mimo że przez dekady nie akcentowano związku między zmianami klimatu a konfliktami zbrojnymi, nie ma wątpliwości, iż degradacja środowiska naturalnego spowodowana działalnością człowieka ma negatywny wpływ na bezpieczeństwo ludzi i w skrajnych przypadkach może prowadzić nawet do konfrontacji z użyciem broni na mniejszą lub większą skalę. Ponadto, niektóre z nich, które już miały miejsce, zaczęto rozpatrywać w kategoriach konfliktów klimatycznych. Często przywoływanym tutaj przykładem jest wojna w Darfurze. Szczegółowo pisze o tym Harald Welzer ${ }^{4}$ i chociaż ocena tego konfliktu bez uwzględnie-

P. D. Williams (red.), op. cit., s. 1-11.

4 H. Welzer, „Wojny klimatyczne”. Za co będziemy zabijać w XXI wieku, Warszawa 2010, s. $73-107$. 
nia innej - poza klimatyczną - perspektywy nie jest właściwa, to argumentów Welzera za postrzeganiem tej wojny przez pryzmat zmian klimatu nie da się nie uwzględnić. Autor podkreśla, iż przed wybuchem wojny w północnym Sudanie w ciągu czterdziestu lat (do końca pierwszej dekady XXI w.) nastąpiło zwiększanie się obszaru pustynnego, co skutkowało ograniczeniem żyźniejszych terenów, nadających się pod uprawy i wypas bydła. Podkreśla również, iż proces ten miał bezpośredni związek ze zmniejszającym się poziomem opadów właśnie z powodu zmian klimatu, ale również z intensyfikacją wypasu bydła, zwiększeniem wycinki lasów, co w konsekwencji prowadziło do erozji i wyjałowienia gleby. Podaje również dane dotyczące wylesiania i wzrostu temperatury - w perspektywie kilku dekad - do roku 2060 na podstawie modeli zmian klimatu przewidywany jest wzrost temperatury w Sudanie o półtora stopnia Celsjusza, zaś średnie opady roczne zmniejszą się o 5\%. W konsekwencji zbiory produktów rolnych mogą zmniejszyć się nawet o 70\%. Przywołuję ten konflikt, ponieważ jest jednym z pierwszych w sposób bardzo dokładny przeanalizowanych z perspektywy klimatycznej. Welzner również podkreśla, iż jest to przypadek, gdzie łatwo ukazać można, jak zmiana klimatu stała się jedną z bezpośrednich przyczyn wybuchu i eskalacji przemocy, prowadząc do wojny domowej. Przytacza na potwierdzenie tej tezy fragment raportu Programu Narodów Zjednoczonych ds. Ochrony Środowiska:

W Darfurze problemy środowiskowe w połączeniu z nadmiernym przyrostem ludności określają warunki konfliktów zbrojnych toczących się na granicach etnicznych - to znaczy pomiędzy „Afrykanami” a „Arabami”. Konflikty, za którymi stoją przyczyny ekologiczne, postrzegane są jako konflikty etniczne - i to przez samych uczestników. Do społecznego upadku dochodzi na skutek katastrofy ekologicznej, ale większość aktorów tego nie dostrzega. To, co widzą, to ataki, grabieże, mordercza przemoc - to znaczy wrogość grupy „ich” wobec grupy „nas”. [...] Trwałego pokoju w Sudanie nie da się osiągnąć tak długo, jak długo warunki życia i środowiska pozostaną takie jak obecnie. Już dziś określają je susze, pustynnienie, brak opadów, wylesienie, mówiąc krótko: egzystencjalne niedostatki, które zmiana klimatu jeszcze pogłębi ${ }^{5}$.

Chociaż jednoznaczne wskazanie, iż przyczyny tej wojny domowej związane są głównie z problemami środowiska naturalnego było krytykowane, to jednak nie sposób nie zgodzić się, iż globalne ocieplenie i dewastacja przyrody w coraz bardziej bezpośredni sposób prowadzi do konfliktów, w których strony uciekają się do użycia przemocy.

5 Studium Programu Narodów Zjednoczonych ds. Ochrony Środowiska, czerwiec 2007, cyt. za: H. Welzer, op. cit., s. 87. Zob. także: Sudan Post-Conflict Environmental. Assessment, UNEP 2007, https://postconflict.unep.ch/publications/UNEP_Sudan.pdf (dostęp: 11.07.2021). 


\section{Perspektywa latynoamerykańska}

Sudan - jak zostało wspomniane - został przywołany jako konflikt przeanalizowany dość dokładnie z perspektywy zmian klimatycznych. Mimo że wiele odróżnia go od konfliktów klimatycznych w Ameryce Łacińskiej, to jednak są pewne podobieństwa - przede wszystkim jeśli chodzi o przyczyny „sporów o zasoby", które możemy odnaleźć, a nawet więcej - odnieść do większości tego rodzaju konfliktów na świecie. Owe „wspólne” przyczyny wybuchu takich konfliktów to niedostatek podstawowych zasobów zapewniających przetrwanie, jak woda pitna, gleba nadająca się do uprawy, spowodowany wzrostem temperatury. Przewiduje się, iż lokalne (ale również regionalne) konflikty o ziemię i wodę będą coraz częstszym zjawiskiem na świecie. Specyfika regionu Ameryki Łacińskiej leży jednak w tym, iż z danych statystycznych i prognoz wynika, że (poza Ameryką Środkową) jest to część świata, której w mniejszym stopniu zagraża niedobór wody spowodowany spadkiem opadów. Według danych Komisji Gospodarczej dla Ameryki Łacińskiej i Karaibów (Economic Commission for Latin America and the Caribbean - CLAC) na region przypada niemal jedna trzecia globalnych zasobów wodnych $^{6}$. A jednak wojny o wodę w tym regionie również miały już miejsce. Najbardziej chyba znane na skalę międzynarodową są wojny o wodę w Boliwii w 2000 r. w Cochabambie. Jednak jako główną przyczynę braku dostępu do wody zdatnej do picia wskazuje się w Ameryce Południowej skażenie wód lub wysychanie zasobów wodnych w wyniku działalności przemysłu wydobywczego lub wielkich inwestycji - paradoksalnie również w energetykę wodną, uważaną dość powszechnie za "proekologiczną". Konflikty o ziemię spowodowane są często polityką powiększania obszarów rolnych, „wypychania" drobnych rolników przez wielkie przedsiębiorstwa agrarne, jak również wycinkę lasów deszczowych pod uprawę i hutnictwo. Można tu zwrócić uwagę na fakt, iż bardzo często stroną poszkodowaną w tych sporach jest ludność rdzenna: mają więc one również wymiar etniczny i związane są $\mathrm{z}$ łamaniem jej praw. Praw, które nierzadko zapisane są w miejscowym ustawodawstwie (jak np. w Konstytucji Brazylii), ale również w konwencjach międzynarodowych, których sygnatariuszami są państwa jednocześnie dające milczące przyzwolenie międzynarodowym, ale również miejscowym, koncernom na ich łamanie.

Jak wspominałam, w największym stopniu do deforestacji Amazonii przyczynia się rolnictwo - w szczególności wycinka lasów pod pastwiska i upra-

6 United Nations, Economic Commission for Latin America and the Caribbean, https:// www.cepal.org/en/topics/water-resources (dostęp: 11.07.2021). 
$\mathrm{wy}^{7}$, ale również pozyskiwanie cennych gatunków drewna. W Ameryce Środkowej dużą role w degradacji gleby i zaniku różnorodności biologicznej ma uprawa palm na produkcję oleju palmowego.

Świadomość konieczności ochrony lasów deszczowych, które charakteryzują się największą różnorodnością biologiczną na Ziemi w ostatnich dekadach, a zwłaszcza w obecnym wieku, znacząco się zwiększyła. Problemy dla bezpieczeństwa związane $\mathrm{z}$ degradacją Zielonych Płuc Ziemi zaczęły trafiać do szerszego grona odbiorców, poza ekologami i specjalistami. Szerokim echem na świecie odbiły się pożary Amazonii na wielką skalę w roku 2019, ale przede wszystkim krytyka prezydenta Jaira Bolsonaro spowodowana jego bardzo opieszałą reakcją na zagrożenie, mimo ostrzeżeń brazylijskich agencji ochrony środowiska ${ }^{8}$, czy oskarżenia formułowane przez prezydenta wobec aktywistów - o celowe podpalanie lasów w celu szukania rozgłosu. Ponadto prezydent Bolsonaro zdecydował się nawet na zwolnienie wysokiego szczebla pracowników agencji, którzy nagłaśniali problemy wycinki lasów lub umieszczali zdjęcia satelitarne pokazujące postępy w dewastacji Amazonii, jak np. Ricarda Magnusa Osório Galvão z Narodowego Instytutu Badań Kosmicznych, który poinformował o znaczącym wzroście wycinki lasów w pierwszym półroczu 2019 r. Ponadto, jak podała Agnecja Reuters, Instytut Chico Mendesa, zajmujący się ochroną bioróżnorodności (Instituto Chico Mendes de Conservação da Biodiversidade - ICMBio) podał dane za rok 2020, z których wynika, że wycinka lasów Amazonii osiągnęła najwyższy poziom w ciągu ostatnich 12 lat ${ }^{9}$. Aby móc zrozumieć rozwój sytuacji w ostatnim roku, musimy opierać się w dużej części na informacjach prasowych, które przedstawiają sytuację z perspektywy aktywistów, gdyż z powodu pandemii COVID-19 dostęp do informacji jest utrudniony. Jednak informacje, jakie przedostają się do wiadomości publicznej, są niepokojące - zwłaszcza że część doniesień wiąże się również z łamaniem praw człowieka.

W lutym 2021 r. świat obiegły zdjęcia „rzek złota” w peruwiańskiej Amazonii zrobione z Międzynarodowej Stacji Kosmicznej 24 grudnia 2020 r. i opublikowane później przez NASA. Ekolodzy, ale również komentatorzy

World Wildlife Fund, https://www.worldwildlife.org/threats/deforestation-and-forest-degradation (dostęp: 11.07.2021).

8 E. Londoño, Bolsonaro Fires Head of Agency Tracking Amazon Deforestation in Brazil, „The New York Times” 2019, August 2, https://www.nytimes.com/2019/08/02/world/ americas/bolsonaro-amazon-deforestation-galvao.html (dostęp: 15.07.2021).

9 J. Spring, Brazil's Bolsonaro Obstructs Environmental Fines Key to Protecting Amazon, „REUTERS” 2021, July 2, https://www.reuters.com/world/americas/brazils-bolsonaro-obstructs-environmental-fines-key-protecting-amazon-2021-07-02/ (dostęp: 15.07.2021). 
i dziennikarze, zwrócili uwagę, iż dzięki fotografiom można pokazać stopień, w jakim zatruwana jest woda w Amazonii przez przemysł wydobywczy, ale także, jaką skalę przybrało nielegalne wydobycie złota w południowo-wschodniej peruwiańskiej części lasów deszczowych w regionie Madre de Dios. Powołując się na komentarz Obserwatorium Ziemi (Earth Observatory) agencji kosmicznej NASA i późniejsze komentarze naukowców, należy wyjaśnić, iż „rzeki złota”, jakie widnieją na zdjęciach, to w rzeczywistości 'kratery' wykopane przez nielegalnie działających górników zwanych garimperos lub niezależnymi górnikami ${ }^{10}$. Obserwatorium Ziemi NASA zwraca również uwagę, iż Peru jest szóstym na świecie producentem złota, a region Madre de Dios jest jednym z największych na świecie centrów „niezależnego górnictwa”, jak nazywany jest nieuregulowany, odbywający się poza strukturami wyznaczonymi przez przepisy i prawo, przemysł górniczy. Co więcej, to właśnie ta działalność jest główną przyczyną wylesiania na tych terenach, jak również zatrucia wody pitnej rtęcią, którą wykorzystuje się w procesie wydobycia złota - uwalniana jest do środowiska w fazie oddzielania kruszcu od skały. Problemy neurologiczne, choroby płuc spowodowane wdychaniem oparów rtęci, choroby nerek spowodowane zatruciem wody dotykają ludność autochtoniczną mieszkającą na tych terenach, jak również niszczą faunę i florę - w tym wiele gatunków endemicznych.

Badacze podkreślają, że deforestacja nie jest spowodowana jedynie samym procesem wydobywczym, lecz także powstawaniem infrastruktury koniecznej do transportu, jak chociażby południowa autostrada międzyoceaniczna, która miała służyć połączeniu Peru z Brazylią, rozwojowi handlu i turystyki. Andrea Nicolau, biorąca udział w projekcie monitorowania andyjskiego regionu (Amazonii Monitoring of Andean Amazon Project), przeanalizowała niemal 3500 kilometrów kwadratowych regionu Madre de Dios, aby prześledzić zmiany w latach 2013-2018. Z jej analizy wynika, że zniknęło około 206 kilometrów kwadratowych lasu na tym terenie, ale znaczące jest, iż największe straty przyniósł ostatni badany rok. Jedną z najbardziej prawdopodobnych przyczyn nasilenia się zjawiska wylesiania, jakie zauważano, jest właśnie ukończenie wspomnianej autostrady - zbiegło się ono w czasie ze wzrostem nielegalnego wydobycia, co ułatwiło garimperos dostęp do tych obszarów ${ }^{11}$. Obserwatorium Ziemi NASA opublikowało także materiały, na których widać poszerzanie się działalności wydobywczej na tych terenach od

10 Gold Rush in the Peruvian Amazon, Earth Observatory, NASA, https://earthobservatory.nasa.gov/images/147891/gold-rush-in-the-peruvian-amazon (dostęp: 27.04.2021).

11 Tracking Peruvian Forest Loss from Space, Earth Observatory, NASA, https://earthobservatory.nasa.gov/images/144841/tracking-peruvian-forest-loss-from-space (dostęp: 17.06.2021). 
maja 2020 do maja $2021 \mathrm{r}^{12}$ Według opublikowanych danych w ciągu ostatnich trzech dekad $\mathrm{w}$ związku $\mathrm{z}$ wydobyciem złota zniszczono około tysiąca kilometrów kwadratowych peruwiańskiej Amazonii. Mimo pewnych sukcesów w ograniczaniu wydobycia, po wprowadzeniu Operacji Merkury ${ }^{13}$, mającej na celu większą kontrolę nad nielegalnym wydobywaniem złota, poza terenami, na których jest ono legalne, ciągle pojawiają się nowe działające bezprawnie kopalnie.

\section{Wydobycie złota a pandemia COVID-19}

Działalność ta nasiliła się jednak jeszcze w okresie pandemii. Mimo zakazów poruszania się i „zamknięcia” kraju nielegalni górnicy wzmogli swoją działalność. Paradoksalnie epidemia mogła wręcz ułatwić działalność nielegalnym górnikom, gdyż działania związane z kontrolą przestrzegania obostrzeń przez obywateli wymagały większego zaangażowania sił porządkowych i bezpieczeństwa, pozwalając tym samym na intensyfikację działań garimperos.

O tym, jak wyglądała działalność wydobywcza w dobie pandemii w Amazonii, możemy się dowiedzieć głównie z doniesień prasowych bazujących na wiadomościach otrzymanych od aktywistów-ekologów, obrońców praw człowieka, gdyż ciągle bardzo trudna sytuacja epidemiczna nie pozwala na dotarcie do tych terenów badaczom $z$ wielu regionów. Jednak potwierdzeniem tego, jak duża jest skala zagrożenia świadczyć może fakt, iż wiele tygodników i gazet polskich opublikowało informacje na ten temat. Jest to o tyle znaczące, że są to problemy odległego regionu i wydawałoby się niebędące w centrum zainteresowania opinii publicznej w Polsce.

Pozwolę sobie wykorzystać kilka informacji prasowych z uwagi na wspomniane ograniczenia w dostępie do bazy źródłowej. W pierwszej kolejności należy podkreślić, że pandemia z jeszcze jednego powodu przyczyniła się do nasilenia rabunkowej gospodarki zasobów naturalnych. Wiąże się to z faktem, iż w czasach kryzysu, jakim bez wątpienia jest globalna pandemia, rosną ceny kruszców - w szczególności złota, które uważane jest za dobrą inwestycję i sposób na lokowanie pieniędzy zabezpieczający przed utratą wartości lepiej niż przechowywanie gotówki nawet w „mocniejszych” walutach.

12 Finding Gold Mining Hotspots in Peru, Earth Observatory, NASA, https://earthobservatory.nasa.gov/images/148439/finding-gold-mining-hotspots-in-peru (dostęp: 17.06.2021).

13 MAAP \#137: New Illegal Gold Mining Hotspot in Peruvian Amazon -Pariamanu, Monitoring of Andean Amazon Project 2021, May 4, https://maaproject.org/2021/mining-peru-pariamanu/ (dostęp: 17.06.2021). 
Mimo ostatniego osłabienia tempa wzrostu, a nawet przejściowych spadków, jeśli weźmiemy pod uwagę okres epidemii COVID-19, kiedy choroba zaczęła się rozprzestrzeniać w Ameryce Południowej - od marca 2020 do lipca 2021 r. włącznie - ceny złota wzrosły o około $12 \%$ za uncję ${ }^{14}$.

Nie może zatem zaskakiwać, iż dla mieszkańców Peru czy Brazylii, państw położonych na kontynencie największych nierówności majątkowych w skali globalnej, praca - nawet nielegalna - przy wydobyciu złota jest postrzegana jako warty ryzyka i pewny sposób utrzymania. Według wspomnianych wcześniej doniesień dziennikarzy ${ }^{15}$, jak również informacji przekazywanych przez religijne organizacje charytatywne, starające się nieść pomoc ludności w Amazonii, wraz $\mathrm{z}$ nasileniem się działalności w czasie epidemii sprowadzono śmiertelne zagrożenie dla społeczności rdzennych na obszarach działalności nielegalnych górników. Niekontrolowane wtargnięcie ludzi, którzy - jak się później okazało - przynieśli ze sobą - świadomie lub nie - koronawirusa na tereny, gdzie rdzenni mieszkańcy nie mieli żadnej pomocy ze strony państwa w walce z zagrożeniem ani realnej możliwości zachowania zaleceń instytucji ochrony zdrowia w walce z chorobą spowodowało katastrofalne wręcz skutki. Najwięcej informacji dotyczy negatywnych konsekwencji, jakie nielegalna działalność w połączeniu z pandemią spowodowała wśród grupy rdzennej Yanomami. Agencja Reuters już w ubiegłym roku w czerwcu opublikowała artykuł alarmującej treści, w którym informowano, iż nielegalna działalność górnicza w okresie epidemii może zagrażać przetrwaniu największej z brazylijskich grup tubylczych, dotychczas funkcjonującej jeszcze we względnej izolacji ${ }^{16}$. Podobnie jak ma to miejsce w Peru, nielegalne wydobycie złota na terenach zamieszkanych przez tę grupę rdzenną w ostatnich latach nasiliło się - szczególnie po wyborze na prezydenta Jaira Bolsonaro, który obiecał zwiększenie wykorzystania Amazonii dla rozwoju gospodarczego kraju. Dziennikarze agencji Reuters zwrócili uwagę, iż szacowana przez urzędników, ale też mieszkańców liczba osób, które pracują $\mathrm{w}$ nielegalnym przemyśle wydobywczym na tych terenach, sięgnęła ( $\mathrm{w}$ momencie publikacji w czerwcu 2020 r.) już 20 tysięcy, podczas gdy liczebność grupy Yanomami szacuje się na około 35-40 tysięcy (dane różnią się w zależności od

14 Dane dotyczące cen złota, Goldenmark, https://goldenmark.com/pl/mysaver/ceny-zlota/ (dostęp: 31.07.2021).

15 W internetowych serwisach informacyjnych w Polsce, M. Winiarska, Duch epidemii Xawariri powrócił z gorączką złota. „Strażnicy Amazonii” umierają razem z nią, https:// tvn24.pl/magazyn-tvn24/duch-epidemii-xawariri-powrocil-z-goraczka-zlota-straznicy-amazonii-umieraja-razem-z-nia,284,4979 (dostęp: 12.05.2021).

16 S. Scarr, A. Boadle, Amazon Gold Rush: Illegal Mining Threatens Brazil's Last Major Isolated Tribe, „REUTERS” 2020, June 25, https://www.reuters.com/article/us-brazil-indigenous-mining-insight-idUSKBN23W2W0 (dostęp: 23.06.2021). 
źródła), z czego prawie dwie trzecie populacji zamieszkuje tereny, które formalnie podlegają ochronie. Na podstawie przeprowadzonej przez agencję Reuters analizy zdjęć satelitarnych rezerwatu społeczności Yanomami, stwierdzono dwudziestokrotny wzrost nielegalnej działalności wydobywczej w ostatnich pięciu latach (licząc do 2020 r.), przede wszystkim wzdłuż dwóch rzek Uraricoera i Mucajai, gdyż woda jest niezbędna w procesie wydobywczym ${ }^{17}$. Autorzy cytują Dario Yawariomę - wiceprzewodniczącego Stowarzyszenia Hutukara Yanomami, który wprost stwierdza, że: „Główną formą transmisji śmiertelnego wirusa do naszych społeczności są nielegalni górnicy. Jest ich tak wielu. Przybywają w helikopterach, samolotach, łodziami i my nie mamy żadnej możliwości, aby stwierdzić, czy [nie] są chorzy na koronawirusa"18.

Lekarze, aktywiści, naukowcy zwracają uwagę, iż dla społeczności rdzennych, które żyją w odmienny sposób - w szczególności fakt, iż podtrzymując swoje tradycje, mieszkają wspólnie, dzieląc przestrzeń zbiorową ze sobą, w bliskim kontakcie, w grupach nawet do kilkuset osób, dzieląc się przedmiotami codziennego użytku, jak i jedzeniem, właściwie nie ma możliwości zachowania zalecanego przez epidemiologów dystansu i higieny. Przez co wirus jest tym bardziej zabójczy dla tego rodzaju społeczności, a badacze regionu obawiają się, iż dla mniejszych grup rdzennych obecna pandemia może oznaczać niemal fizyczne wyniszczenie. W przypadku grupy Yanomami szacuje się, że zainfekowane zostanie co najmniej $40 \%$ populacji ${ }^{19}$. Wspomniani przeze mnie dziennikarze dowiedzieli się także od Dario Yawariomy, iż żaden przedstawiciel rządowej agencji ds. ludności rdzennej (Funai) w pierwszych miesiącach epidemii nie pojawił się, aby zapoznać się z sytuacją mieszkańców.

Bierności władz nie można nazwać zaskakującą, gdyż Jair Bolsonaro obiecywał zalegalizowanie działalności garimpeiros. Ponadto z powodu wzrostu popytu na złoto eksport tego kruszcu z Brazylii również się zwiększa. Trafia ono głównie do Indii: w 2019 r. stanowił on 12,7\% całości eksportu brazylijskiego do Indii ${ }^{20}$, a w ciągu pierwszych ośmiu miesięcy 2020 r. zanotowano wzrost eksportu złota z Brazylii do Indii o $35 \%{ }^{21}$.

17 Ibidem.

18 Ibidem. Tłumaczenie własne autorki.

19 V. Vaishnavi Rathore, Brazilian Gold has an Environmentally Hazardous Supply Chain, and India is a Part of It, The Bastion. Development in Depth 2020, July 29 (dostęp: 23.06.2021).

20 Observatory of Economic Complexity (OEC), https://oec.world/en/profile/bilateral-country/ind/partner/bra (dostęp: 30.06.2021).

21 D. Phillips, Goldmining Having Big Impact on Indigenous Amazon Communities, „The Guardian” 2020, October 7, https://www.theguardian.com/environment/2020/oct/07/goldmining-having-big-impact-on-indigenous-amazon-communities (dostęp: 30.06.2021). 
Biorąc pod uwagę politykę i nastawienie prezydenta Jaira Bolsonaro, który postrzega Amazonię głównie jako potencjalne źródło dochodu, a nie źródło bogactwa przyrodniczego, które należy chronić, nie dziwi również jego brak zaangażowania w ochronę ludności rdzennej (jeszcze przed pandemią twierdził, iż teren rezerwatu, na którym żyją Yanomami, jest nieproporcjonalnie duży do liczby jego mieszkańców). Przed wybuchem epidemii wiele odizolowanych społeczności natywnych na co dzień nie miało dostępu do opieki medycznej. Nie zaskakuje więc fakt, iż obecnie nie prowadzi się oficjalnych statystyk, dotyczących przypadków koronawirusa wśród ludności autochtonicznej, a ponadto znikoma jej część poddawana jest badaniom i testom na koronawirusa. Pod wpływem wydanego przez brazylijski sąd federalny nakazu ostatecznie rząd zmuszony był przedsięwziąć kroki mające na celu ochronę ludności tubylczej. Prezydent Jair Bolsonaro zadecydował o wysłaniu do rezerwatu w lipcu 2020 r. personelu medycznego i wojska wyposażonego w testy na obecność koronawirusa i maski ochronne. Jednak podobnie jak w całym kraju środki i zasoby ludzkie, jakimi dysponowano, w połączeniu z podejściem prezydenta, który bardzo długo lekceważył zagrożenie, nie pozwoliły na skuteczne przeciwstawienie się chorobie. $\mathrm{Na}$ tej podstawie można było spodziewać się, iż taki sam scenariusz powtórzy się w przypadku szczepień. Ostatnie doniesienia zdają się to potwierdzać. W kwietniu 2021 r. agencja Reuters poinformowała o przypadkach wymiany nielegalnie wydobywanego przez górników złota na szczepionki, które przeznaczone miały być dla ludności Yanomami. Doprowadziło to do śledztwa prokuratury federalnej. Hutukara’s Dário Kopenawa Ianomâmi powiedział, iż społeczność Yanomami jeszcze przed dotarciem szczepionek informowała, że leki i zasoby medyczne, które miały trafiać do ludności rdzennej, były nielegalnie sprzedawane górnikom ${ }^{22}$.

\section{Podsumowanie i wnioski}

$\mathrm{Na}$ podstawie przedstawionych przykładów, które opisane zostały w dużej mierze na bazie informacji z mediów światowych, można wnioskować, iż konflikty o zasoby naturalne w Ameryce Łacińskiej - w przedstawionych przypadkach w Amazonii - nie tylko trwają, ale wręcz przybierają na sile. Splot okoliczności - jak światowa pandemia, która pociągnęła za sobą wzrost cen złota na światowych rynkach, ale również pozostawanie przy władzy po-

22 L. Paraguassu, R. Brito, Brazil Investigates Reports of Vaccines Being Exchanged for Illegal Gold, „REUTERS” 2021, April 15, https://www.reuters.com/world/brazil-investigates-reports-vaccines-being-exchanged-illegal-gold-2021-04-14/ (dostęp: 30.06.2021). 
pulistycznego prezydenta Jaira Bolsonaro w Brazylii, spowodował zaostrzenie się konfliktu. Warto podkreślić, iż dewastacja środowiska naturalnego ma tutaj bezpośredni wpływ na prawa ludności rdzennej. I to prawa, które zaliczane są do tzw. pierwszej kategorii praw człowieka, nawet tak podstawowe prawo każdego z nas - prawo do życia. Mimo że prawa tzw. trzeciej kategorii jak prawo do czystego środowiska naturalnego nie zostały jeszcze objęte powszechnie obowiązującymi konwencjami międzynarodowymi, to m.in. na forum Organizacji Narodów Zjednoczonych dostrzeżono konieczność uznania prawa dostępu do wody pitnej za prawo podstawowe.

We wstępie artykułu wspomniałam, iż następuje zmiana postrzegania bezpieczeństwa wyłącznie przez pryzmat bezpieczeństwa państwa, a coraz większy nacisk kładzie się również na perspektywę zagrożenia dla jednostek i dla planety wynikającego z niszczenia środowiska naturalnego. Przyglądając się konfliktom klimatycznym w Ameryce Południowej, można zauważyć, iż szczególne koszty dewastacji środowiska ponosi ludność rdzenna lub z najuboższych grup społecznych. Skala ubóstwa również ma znaczenie dla nasilania się konfliktów o zasoby spowodowanych zmianami środowiska naturalnego. Jeśli analizujemy przyczyny degradacji środowiska naturalnego w regionie latynoamerykańskim, to ubóstwo społeczności lokalnych jest jednym z głównych elementów wpływających na skalę m.in. wycinki lasów deszczowych i zaangażowania w nielegalny przemysł wydobywczy. Działalność ta daje możliwości zarobku społecznościom, które często nie dostrzegają innych sposobów utrzymania się.

Jednym z czynników jest również wysoki poziom korupcji - mimo formalnej ochrony prawnej, jaką mają rezerwaty przyrody, a także ludność je zamieszkująca. Korupcja ma zdecydowany wpływ na fakt, iż przepisy obowiązującego prawa pozostają martwe, a prawa ludności autochtonicznej są łamane. W przypadku Brazylii znaczący wpływ na rozwój sytuacji miało również przyzwolenie władz - zwłaszcza zaś prezydenta Bolsonaro. Warto zwrócić uwagę, iż już w czasie kampanii wyborczej nie stronił on od haseł, które zachęciły jego zwolenników do ataków na ludność tubylczą. Jeszcze przed objęciem przez Bolsonaro urzędu prezydenta, ale już po wyborach, liczba ataków na przedstawicieli ludności rdzennej była większa niż w analogicznym okresie w roku poprzednim. Podobnie wypowiedzi głowy państwa, lekceważące w tonie, jeśli chodzi o konieczność ochrony dziedzictwa naturalnego, jak i czystki w agencjach odpowiedzialnych za ochronę środowiska, stworzyły sprzyjający klimat dla działań szkodliwych dla przyrody. Nie można zapomnieć, iż w grę wchodzą tutaj interesy wielkiego biznesu - obszarników, hodowców bydła i rolników uprawiających np. soję, którym podejście obecnego prezydenta bardzo odpowiada i któremu to środowisku Jair Bolsonaro sprzyja. 
Jednak wpływ na niszczenie środowiska mają również instytucje międzynarodowe. Noblista z dziedziny ekonomii Joseph Stiglitz, który przyznaje, iż jego przywiązanie do zasad rynkowych w duchu liberalizmu, bez uwzględniania skutków społecznych neoliberalnej polityki gospodarczej, uległo zmianie po doświadczeniach w regionie Ameryki Południowej, często wskazuje, iż Bank Światowy (współdziałając nierzadko z Międzynarodowym Funduszem Walutowym) najchętniej finansuje ogromne i kapitałochłonne inwestycje, bez uwzględniania lepiej dostosowanych do lokalnych warunków rozwiązań. Dotyczy to także budowy wielkich hydroelektrowni w Brazylii i innych państwach regionu.

Ponieważ $\mathrm{w}$ artykule skupiłam się głównie na niezależnym górnictwie, nie wspominałam o praktykach stosowanych przez wielkie koncerny wydobywcze, które nierzadko ponoszą dużą odpowiedzialność za zanieczyszczenia rtęcią czy eksploatację zasobów wodnych powodującą odcięcie od źródeł wody pitnej lokalnych społeczności. Jest to jednak ważne z punktu widzenia przeciwdziałania niszczeniu środowiska naturalnego, ponieważ są to firmy z kapitałem międzynarodowym - także europejskim, amerykańskim czy kanadyjskim. Trudno ich wpływ pominąć całkowicie, a zwłaszcza związany z ich działalnością element, niezwykle istotny w tej dyskusji, czyli chęć maksymalizacji zysku przy jednoczesnym cięciu kosztów (niektórzy aktywiści nazywają ten element wręcz chciwością). Firmy z zagranicznym kapitałem stosują praktyki, jakie nie byłyby dozwolone w krajach ich pochodzenia.

Socjolog, profesor Robert Bullard użył określenia „niewidzialne społeczności”, odnosząc się do miejskich gett, dzielnic, enklaw etnicznych, wiejskich obszarów ubóstwa. Zwrócił uwagę, iż społeczności złożone głównie z ludzi „białych” i przedstawicieli klasy średniej są w stanie osiągnąć sukces w walce o ochronę swojej okolicy, stosując politykę „nie w moim ogródku” w stosun$\mathrm{ku}$ do ryzykownych pod względem wpływu na środowisko inwestycji. Zauważył również, iż władze reagowały szybciej i z większą uwagą na ich skargi dotyczące niewystarczającej dbałości o środowisko, jeśli padały one ze strony grup zamożniejszych obywateli. Uważa on, iż słabsze pod względem wpływu politycznego niewidzialne społeczności funkcjonują tam, gdzie firmy sytuują składowiska odpadów, spalarnie, są częścią lub przyzwalają na obarczone ryzykiem działania, jak m.in. działalność wydobywcza wymagająca użycia niebezpiecznych substancji lub pozostawiająca toksyczne produkty uboczne. Ponieważ korporacje często zaangażowane są w działalność, która może powodować zanieczyszczenie środowiska naturalnego za przyzwoleniem władz, ale bez właściwego nadzoru z ich strony, prawo nie chroni w sposób odpowiedni tych społeczności. Wręcz przeciwnie: „ludzie, w których rękach skoncentrowana jest władza polityczna i ekonomiczna stosowali prawo śro- 
dowiskowe w sposób, który prowadzi do sytuacji, w której ludność uboga ponosi nieproporcjonalnie dużą część ryzyka związanego z niszczeniem środowiska"23. Ten opis profesora Bullarda znakomicie pasuje do sytuacji ludności rdzennej i ubogich mieszkańców regionu latynoamerykańskiego.

Warto uwzględnić tę perspektywę również dlatego, iż to konsumenci krajów rozwiniętych w dużej części odpowiadają za popyt na produkty z cennych gatunków drewna, wyroby ze szlachetnych kruszców, ale również globalnie za rozwój konsumpcjonizmu. I to na nas - konsumentach spoczywa również obowiązek, aby walczyć z "modą" na częstą wymianę wyposażenia, sprzętu, ubrań - gdyż ich produkcja i odpady powodują znaczne zanieczyszczenie i przyczyniają się do degradacji środowiska naturalnego w odległych regionach świata. Jako konsumenci powinniśmy świadomie dokonywać wyboru produktów, o których wiemy, że są produkowane w sposób zrównoważony, ale również domagać się od przedsiębiorstw europejskich stosowania do przepisów ochrony środowiska także poza naszym regionem.

W tym kontekście należy zaznaczyć, iż na poziomie Unii Europejskiej podjęte zostały pewne działania w tym kierunku. Ósmego lutego 2021 r. zakończyły się konsultacje publiczne w ramach UE, w kategorii tematycznej „Sprawiedliwość i prawa podstawowe", w których mogli wypowiedzieć się obywatele państw unijnych, przedstawiciele biznesu, organizacji międzynarodowych i in. nad projektem "Sustainable corporate governance” - dotyczącym m.in. odpowiedzialności funkcjonowania przedsiębiorstw dla zrównoważonego rozwoju i ochrony środowiska, która będzie sięgała również poza granice państw Unii Europejskiej. Po wnikliwym zapoznaniu się z opiniami reprezentantów różnych grup ${ }^{24}$ można było zauważyć, iż projekt jest wprawdzie krytykowany przez środowiska przedsiębiorców, ale również polityków, zaś pozytywnie odnoszą się do niego zarówno działacze na rzecz ochrony środowiska, jak i obrońcy praw człowieka. Przedstawiciele biznesu i polityki wskazują na uzasadnione

23 D. R. Bullard, Environmental Racism and „Invisible” Communities, „West Virginia Law Review. The Research Repository WVU” 1994, vol. 94(4), s. 96; J. Todd, Trade Treaties, Citizen Submissions, and Environmental Justice, „Ecology Law Quarterly. Environmental Governance and Technology” 2017, vol. 44(1), s. 95-96.

24 Materiały dotyczące projektu były powszechnie dostępne na oficjalnych stronach unijnych. Autorka zapoznała się z opiniami różnych grup społecznych i interesu, jak również uzupełniła i przesłała formularz opinii przeznaczony dla obywateli Unii Europejskiej. Na stronach w języku polskim projekt zatytułowany był „Zrównoważony ład korporacyjny", https://ec.europa.eu/info/law/better-regulation/have-your-say/ initiatives/12548-Sustainable-corporate-governance/public-consultation_pl (dostęp: 3.09.2021), na której w chwili obecnej można pobrać zestawy odpowiedzi i oceny skutków w plikach w formacie PDF. 
obawy, iż jego wprowadzenie oznaczać będzie zwiększenie kosztów produkcji, a zapewne również wzrost cen dla konsumentów. Z drugiej strony obywatele UE muszą uświadomić sobie, że nasze decyzje mają znaczenie, iż mają wpływ także na działania podejmowane na arenie międzynarodowej - już poprzez sam wybór rządzących nami polityków. Mogą domagać się od rządów, aby nie zawierały umów handlowych z państwami, o których wiemy, że prowadzić będą inwestycje w sposób niszczący środowisko, jak również zaprzestania pomocy wojskowej dla państw, które używają następnie sił bezpieczeństwa, aby walczyć przemocą z ludnością rdzenną i obrońcami środowiska, co jest częstą praktyką w krajach Ameryki Środkowej.

Należy podkreślić, iż spory mające w tle działania wydobywcze są konfliktogenne w kilku wymiarach, ale najbardziej dramatyczne w skutkach w zakresie uznania praw ludności rdzennej. Mają swoje źródło w długiej historii wykluczenia najbardziej wrażliwych grup społecznych, ale również w odmiennym rozumieniu sposobów wykorzystania zasobów (znacząco różni się ono z perspektywy górników czy korporacji wydobywczych i perspektywy społeczności rdzennych). Ponadto cechą charakterystyczną konfliktów klimatycznych w regionie jest zintensyfikowanie użycia siły ze strony aparatu państwowego i nasilenie naruszeń praw człowieka, na które to problemy zwraca uwagę m.in. Elisabet Dueholm Rasch ${ }^{25}$. Mieszkańcy krajów rozwiniętych, zamożniejszych nie powinni ignorować tego problemu, zwłaszcza że niezrównoważona eksploatacja zasobów naturalnych wywołuje liczne konflikty społeczne i przemoc. Uzasadnione są prognozy, iż w przyszłości będzie to przyczyną coraz częstszych zbrojnych konfliktów wewnętrznych. Jeśli nawet perspektywa ta w krajach rozwiniętych wydaje się na razie odległa, to dla bezpieczeństwa naszego i przyszłych pokoleń, w rozumieniu globalnym, bezpieczeństwa planety, nieunikniona ${ }^{26}$.

A jeśli dla naszego przetrwania zmiany są nieuchronne, to może warto już dziś odpowiedzieć na prośby i apele przedstawiciela plemienia Yanomamów Daviego Kopenawy:

My, szamani, pracujemy również dla was, białych. Wiemy, że nasza planeta się zmienia. Wiemy, w jakim stanie jest Amazonia. Mamy świadomość, że nadwyrężanie natury jest niebezpieczne, że niszcząc lasy deszczowe, przecinamy tętnice przyszłości, powodując, że siła świata odpływa. Niebo nad nami jest pełne dymu, bo nasze lasy są wycinane

25 E. Dueholm Rasch, Citizens, Criminalization and Violence in Natural Resource Conflicts in Latin America, „European Review of Latin American and Caribbean Studies / Revista Europea de Estudios Latinoamericanos y del Caribe” 2017, vol. 103, s. 131-142.

26 Ekonomiści i socjologowie ostrożnie mówią o zmianie nawyków w wyniku pandemii również w krajach rozwiniętych - spadku sprzedaży np. w branży tekstyliów, choć zbyt wcześnie jest jeszcze, aby ocenić, czy będą one trwałe. 
i palone. Deszcze przychodzą późno, Słońce zachowuje się dziwnie. Płuca Ziemi są zanieczyszczone. Świat jest chory. Las umrze, jeśli dalej będzie niszczony. Dokąd pójdziemy, jeśli biali zniszczą nasz świat?

Świat musi usłyszeć wołanie Ziemi, która prosi o pomoc. Jeżeli będziecie dalej zabijać ludzi i niszczyć naturę, wydobywać całe złoża ropy, minerałów i drewna, nasza planeta zachoruje i wszyscy umrzemy ${ }^{27}$.

\section{Bibliografia}

Bullard R. D., Environmental Racism and „Invisible” Communities, „West Virginia Law Review. The Research Repository WVU” 1994, vol. 94(4).

Dueholm Rasch E., Citizens, Criminalization and Violence in Natural Resource Conflicts in Latin America, „European Review of Latin American and Caribbean Studies / Revista Europea de Estudios Latinoamericanos y del Caribe" 2017, vol. 103.

Finding Gold Mining Hotspots in Peru, Earth Observatory, NASA, https://earthobservatory.nasa.gov/images/148439/finding-gold-mining-hotspots-in-peru (dostęp: 17.06.2021).

Gold Rush in the Peruvian Amazon, Earth Observatory, NASA, https:/earthobservatory.nasa.gov/images/147891/gold-rush-in-the-peruvian-amazon (dostęp: 27.04.2021).

Goldenmark, https://goldenmark.com/pl/mysaver/ceny-zlota/ (dostęp: 31.07.2021).

Londoño E., Bolsonaro Fires Head of Agency Tracking Amazon Deforestation in Brazil, „The New York Times” 2019, August 2, https://www.nytimes. com/2019/08/02/world/americas/bolsonaro-amazon-deforestation-galvao.html (dostęp: 15.07.2021).

MAAP \#137: New Illegal Gold Mining Hotspot in Peruvian Amazon - Pariama$n u$, Monitoring of Andean Amazon Project, May 4, 2021, https://maaproject.org/2021/mining-peru-pariamanu/ (dostęp: 17.06.2021).

Observatory of Economic Complexity (OEC), https://oec.world/en/profile/bilateral-country/ind/partner/bra (dostęp: 30.06.2021).

Paraguassu L., Brito R., Brazil Investigates Reports of Vaccines Being Exchanged for Illegal Gold, „REUTERS” 2021, April 15, https://www.reuters. com/world/brazil-investigates-reports-vaccines-being-exchanged-illegal-gold-2021-04-14/ (dostęp: 30.06.2021).

27 M. Winiarska, Duch epidemii Xawariri powrócił z goraczką złota. „Strażnicy Amazonii” umieraja razem $z$ nia, https://tvn24.pl/magazyn-tvn24/duch-epidemii-xawariri-powrocil-z-goraczka-zlota-straznicy-amazonii-umieraja-razem-z-nia,284,4979 (dostęp: 12.05.2021). 
Phillips D., Goldmining Having Big Impact on Indigenous Amazon Communities, „The Guardian” 2020, October 7, https://www.theguardian.com/ environment/2020/oct/07/goldmining-having-big-impact-on-indigenous-amazon-communities (dostęp: 30.06.2021).

Scarr S., Boadle A., Amazon Gold Rush: Illegal Mining Threatens Brazil's Last Major Isolated Tribe, 2020, June 25, https://www.reuters.com/article/us-brazi1-indigenous-mining-insight-idUSKBN23W2W0 (dostęp: 23.06.2021).

Spring J., Brazil's Bolsonaro Obstructs Environmental Fines Key to Protecting Amazon, „REUTERS” 2021, July 2, https://www.reuters.com/world/americas/brazils-bolsonaro-obstructs-environmental-fines-key-protecting-amazon-2021-07-02/ (dostęp: 15.07.2021).

Sudan Post-Conflict Environmental Assessment, UNEP 2007, https://postconflict.unep.ch/publications/UNEP_Sudan.pdf (dostęp: 11.07.2021).

Todd J., Trade Treaties, Citizen Submissions, and Environmental Justice, „Ecology Law Quarterly. Environmental Governance and Technology” 2017, vol. 44(1).

Tracking Peruvian Forest Loss from Space, Earth Observatory, NASA, https:// earthobservatory.nasa.gov/images/144841/tracking-peruvian-forest-loss-from-space (dostęp: 17.06.2021).

United Nations, Economic Commission for Latin America and the Caribbean, https://www.cepal.org/en/topics/water-resources (dostęp: 11.07.2021).

Williams P. D. (red.), Studia bezpieczeństwa, Kraków 2012.

Winiarska M., Duch epidemii Xawariri powrócit z goraczką złota. „Strażnicy Amazonii" umieraja razem $z$ nia, https://tvn24.pl/magazyn-tvn24/duch-epidemii-xawariri-powrocil-z-goraczka-zlota-straznicy-amazonii-umieraja-razem-Z-nia,284,4979 (dostęp: 12.05.2021).

World Bank Open Data, https://data.worldbank.org (dostęp: 1.07.2021).

Vaishnavi Rathore V., Brazilian Gold has an Environmentally Hazardous Supply Chain, and India is a Part of It, „The Bastion. Development in Depth” 2020, July 29 (dostęp: 23.06.2021).

Welzer H., „Wojny klimatyczne” Za co będziemy zabijać w XXI wieku?, Warszawa 2010.

World Wildlife Fund, https://www.worldwildlife.org/threats/deforestation-andforest-degradation (dostęp: 11.07.2021). 